\title{
The Reproductive Biology of the Softshell Clam, Mya arenaria, in Ireland, and the Possible Impacts of Climate Variability
}

\author{
M. E. Cross, S. Lynch, A. Whitaker, R. M. O’ Riordan, and S. C. Culloty \\ Aquaculture and Fisheries Development Centre, School of Biological, Earth and Environmental Sciences, \\ University College Cork, Cork, Ireland \\ Correspondence should be addressed to M. E. Cross, maud.cross@ucc.ie
}

Received 3 January 2012; Revised 2 March 2012; Accepted 2 March 2012

Academic Editor: Hans Ulrik Riisgård

Copyright ( $\odot 2012$ M. E. Cross et al. This is an open access article distributed under the Creative Commons Attribution License, which permits unrestricted use, distribution, and reproduction in any medium, provided the original work is properly cited.

Little is known about the biology of the softshell clam in Europe, despite it being identified as a potential species to culture for food in the future. Monthly samples of the softshell clam, Mya arenaria, were collected intertidally from Co. Wexford, Ireland, over a period of sixteen months. The mean weight of sampled individuals was $74 \pm 4.9 \mathrm{~g}$ and mean length was $8.2 \pm 0.2 \mathrm{~cm}$. Histological examination revealed a female-to-male ratio of $1: 1.15$. In 2010, M. arenaria at this site matured over the summer months, with both sexes either ripe or spawning by August. A single spawning event was recorded in 2010, completed by November. Two unusually cold winters, followed by a warmer-than-average spring, appear to have affected $M$. arenaria gametogenesis in this area, potentially affecting the time of spawning, fertilisation success, and recruitment of this species. No hermaphrodites were observed in the samples collected, nor were any pathogens observed. Timing of development and spawning is compared with the coasts of eastern North America and with other European coasts.

\section{Introduction}

The softshell clam, Mya arenaria, is widely distributed in coastal and intertidal soft substrates in boreal waters and is often a dominant species in benthic communities [1]. Mya arenaria currently occupies a wide geographical range in the northern hemisphere, on the east and west coasts of North America, where it is commercially important for fisheries and aquaculture [2, 3]. In 2008 alone, the National Marine Fisheries Service of USA reported approximately 1.73 million $\mathrm{kg}$ of M. arenaria harvested, worth in excess of $€ 16$ million [4].

The present European distribution of M. arenaria ranges from Northern Norway to Portugal, including the Black Sea [5-7], with recent reports of its introduction to the Mediterranean Sea [4]. Mya arenaria is rarely collected for food or bait in European waters, but it is an ecologically important food source for fish such as plaice (Pleuronectes platessa) and flounder (Platichtys flesus) [6], shrimp, sandworms, crabs, and wading birds such as oystercatchers (Haematopus ostralegus) and curlew (Numenius arquata) [8]. Due to the softshell clams' ability to survive and reproduce in a variety of differing areas such as mud and gravel, it could be an ideal species to culture in European waters in the future.
Mya arenaria are widespread around all Irish and British coasts $[9,10]$, but little information is currently available on reproductive biology in these areas.

Previous work in the United States has revealed that the sexes of $M$. arenaria are usually separate, with a sex ratio of $50: 50[11,12]$. On eastern North American coasts M. arenaria usually begins spawning in May or June and can continue for two to three months. Though most sampled populations of $M$. arenaria spawn once a year [13], there have been examples of two spawning periods occurring, in spring and autumn $[12,14]$. In European waters single spawning events have been recorded in the Black Sea [15], the Wadden Sea $[16,17]$, the west coast of Sweden [18], and on the east coast of Denmark [19], while biannual spawning events were observed in Oslofjord, Norway [20], and the south coast of England [21]. To date, details of the reproductive cycle of $M$. arenaria in the Irish Sea have not been recorded.

Environmental conditions such as water temperature, food availability, and the presence of pollution have been shown to affect gametogenesis and spawning of $M$. arenaria $[12,22]$, and the increase or decrease in sea surface temperature (SST) can affect the distribution and abundance of some 
bivalve species [23]. There have been records of spawning at different temperatures across the native range of M. arenaria, from $4^{\circ} \mathrm{C}$ to $25^{\circ} \mathrm{C}[14,24]$. In the Celtic/Biscay shelf, sea water temperatures are predicted to increase between 1.5 and $5^{\circ} \mathrm{C}$ over the next 100 years [25], with global temperature hypothesized to increase 1.8 to $4^{\circ} \mathrm{C}$ by the end of the $21 \mathrm{st}$ century [26]. However, the rate of change of temperature is highly variable spatially [27], with extreme episodes of unusual temperatures occurring in some areas. Some studies are indicating that annual seawater temperatures may rise in European, including Irish, waters in the future $[28,29]$, while the winter of 2009-2010 in Ireland was the coldest in 50 years, with December 2010 being the coldest on record [30].

This study was undertaken due to the lack of knowledge of the reproductive biology of Mya arenaria in Irish waters, and their potential as a future commercial food species. The potential effects of climate change on this species can be investigated in the short term (the effect of cold winters) and provide a baseline for longer term climate change studies in European waters. The aims of the current paper were to investigate, using histological analysis, the annual reproductive cycle of M. arenaria in Ireland under natural conditions, in an area close to the centre of the introduced European range and to determine whether there are differences in the reproductive cycle between that recorded in the Irish Sea and other European sites and whether patterns are similar to those observed in the native range in eastern North America.

\section{Materials and Methods}

2.1. Study Site. Bannow Bay, Co. Wexford is an estuary on the southeast coast of Ireland, located at the interface between the Celtic and Irish Seas $\left(52^{\circ} 27^{\prime} \mathrm{N} 006^{\circ} 47^{\prime} \mathrm{W}\right)$. It covers an area of $c a 1050 \mathrm{ha}$, is $8 \mathrm{~km}$ long and between 1 and $3 \mathrm{~km}$ wide [31]. The intertidal habitat consists of mud and sand flats, and approximately $75 \%$ of the bay is uncovered at average low tide. The tidal range at Bannow Bay is 0.6 to 3.8 metres. There is oyster cultivation on the eastern side of the estuary, and the surrounding land mainly supports dairy and arable farming.

2.2. Sampling. Softshell clam, M. arenaria, specimens $(n \approx$ $30)$ were collected by digging in the lower intertidal $\left(52^{\circ} 13^{\prime}\right.$

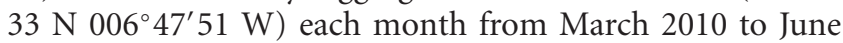
2011, generally during the first week of each month in low Spring tides. Specimens were located in the muddy sediment by identifying the characteristic "key-hole" shaped opening left by the siphons. Digging beside these siphon holes allowed for the collection of individuals without breaking the brittle shells. Mya arenaria were usually found at a depth of $30 \mathrm{~cm}$, though could be as deep as $40 \mathrm{~cm}$ during the colder months. The first 30 siphon holes identified were dug out and the individuals collected below these apertures were used. Most key-hole shaped openings were produced by larger individuals, and very few small $M$. arenaria were encountered while digging. Density estimates were not obtained as the substrate containing $M$. arenaria, consisting of mud and gravel, was not suitable for collecting density data. Mya arenaria were transported to a cold room $\left(4^{\circ} \mathrm{C}\right)$ within four hours of collection and left overnight for dissection the next morning. Each clam was numbered and the total wet weight $(\mathrm{g})$, shell length from anterior to posterior end $(\mathrm{cm})$, and width from dorsal side to ventral side $(\mathrm{cm})$ of each individual were recorded. No sample could be taken in December 2010 due to severe weather conditions preventing travel to the sampling area.

A continuous temperature monitor, the Stowaway Tidbit Weatherproof \& Waterproof Temperature Logger, was deployed underwater $10 \mathrm{~m}$ from the $M$. arenaria collection site in Bannow Bay from June 2010. The monitor recorded ambient temperature at 16 minute intervals, and the monthly mean was calculated from this date to the end of the study. Data were obtained from the monitor using an Optic base Station/Coupler Kit and BoxCar Pro 4.3 Starter Kit Software. As temperature for the site was only available from June 2010, air temperature data from January 2008 to July 2011 was also obtained from Met Eireann for Johnston Castle, which is approximately $20 \mathrm{~km}$ from Bannow Bay.

2.3. Histological Techniques. The soft tissue of each clam was dissected within 24 hours of collection from the fresh individuals. Two cuts through the body of the animal provided a transverse section of the visceral mass, which contained the gonad, renal gland and digestive tract, and sections of the gill and mantle. The tissue was fixed in Davidson's solution for 48 hours and stored at $4^{\circ} \mathrm{C}$. Slides were prepared using standard histological techniques, where tissues were dehydrated in alcohol, cleared in xylene, embedded in paraffin wax, sectioned at $7 \mu \mathrm{m}$, and stained with Harris' hematoxylin and eosin before being mounted on clean standard microscope slides [32]. The prepared microscope slides were examined using 10x, 20x, and 40x magnification, to determine sex and stage of reproductive development. Individuals were also screened for the presence of any parasites and abnormal conditions or pathologies.

2.4. Staging of Gonadal Development. Clam reproductive maturity was categorised into five stages using the maturity scale described by Brousseau [12], whereby maturity stages were designated as "indifferent, developing, ripe, spawning, and spent." When more than one developmental stage was present in a single individual, the maturity was scored based on the most prevalent stage.

The indifferent stage of female Mya arenaria is identified when the distinctive female inclusions are visible in the follicle cells and extremely small primary oocytes are present in the alveolar membrane. The developing stage is recognised by an increase in the number and the size of oocytes. A central lumen is present in each follicle, into which protrude the stalked oocytes. In the ripe female there are many mature, spherical oocytes which appear to be free within the follicular lumen. In the spawned stage, the mature oocytes are gradually discharged. Emptying follicles and the cessation of oogenesis in all follicles is characteristic of this stage. In the spent stage, unspent oocytes in the early phases of cytolysis are present. These appear in the lumen as large, darkly staining bodies with obscure nuclei. Follicle cells begin to reinvade the follicles from the basal membrane. 


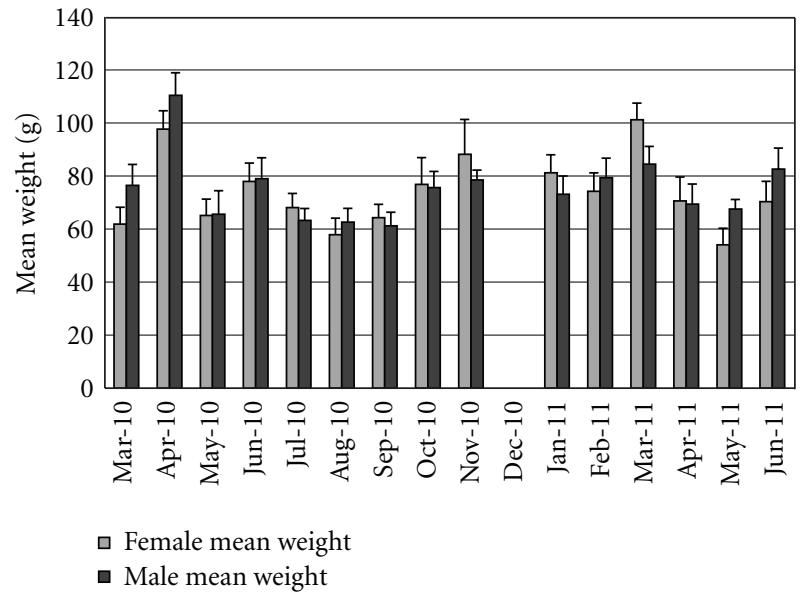

Figure 1: Mean weight ( \pm S.D.) of female and male Mya arenaria sampled at Bannow Bay from March 2010 to June 2011.

During the indifferent stage of male Mya arenaria the follicles contain the aberrant forms, multinucleated nonpycnotic cysts and pycnotic cells. The basal membrane and follicle cells are the dominant structural elements, with a few primary spermatocytes or spermatogonia visible at the periphery of the lumen. In the developing stage, the maturation and proliferation of the spermatocytes takes place. In the ripe male clam the follicle is filled with dense radiating bands of spermatozoa, the tails of which project into the central lumen. In the spawned stage the follicle is characterised by fewer spermatozoa than the ripe clam. A few spermatozoa remain in the radiating bands but the rows of follicle cells gradually increase to replace the spawned spermatozoa. In the spent male, the follicles are almost completely filled with follicle cells and the reduced lumen contains a few sex cells [12].

\section{Results}

3.1. Measurements. Of the 432 individuals collected over 16 months from March 2010 to June 2011, the average weight of all individuals was $74 \mathrm{~g} \pm 4.9 \mathrm{~g}$ (Figure 1) with the lightest individual collected weighing $3.1 \mathrm{~g}$, and the heaviest $200 \mathrm{~g}$. Over the months sampled, mean monthly values ranged from $60.5 \mathrm{~g} \pm 4 \mathrm{~g}$ to $103 \mathrm{~g} \pm 5.4 \mathrm{~g}$. The average length of all M. arenaria collected was $8.2 \mathrm{~cm} \pm 0.2 \mathrm{~cm}$ (Figure 2). Individuals collected ranged from 2.6 to $11.6 \mathrm{~cm}$ in length, with the mean monthly lengths ranging from $7.4 \mathrm{~cm} \pm 0.1 \mathrm{~cm}$ to $9.4 \mathrm{~cm} \pm 0.1 \mathrm{~cm}$. Due to the nature of collection, only softshell clams with visible siphon holes were collected. Very few spat were observed at this area while sampling. All lengths and weights of Mya arenaria were observed in various stages of gametogenesis apart from males under $5.9 \mathrm{~cm}$ (Figures 5 , 6,8 , and 9 ).

The average weight and length of female individuals were $74 \mathrm{~g} \pm 3.5 \mathrm{~g}$ and $8.1 \mathrm{~cm} \pm 0.2 \mathrm{~cm}$, respectively, while the average weights and lengths of male individuals were $75 \mathrm{~g} \pm 3.2 \mathrm{~g}$ and $8.2 \mathrm{~cm} \pm 0.1 \mathrm{~cm}$. On average, female individuals were both lighter and shorter than male M. arenaria, though this

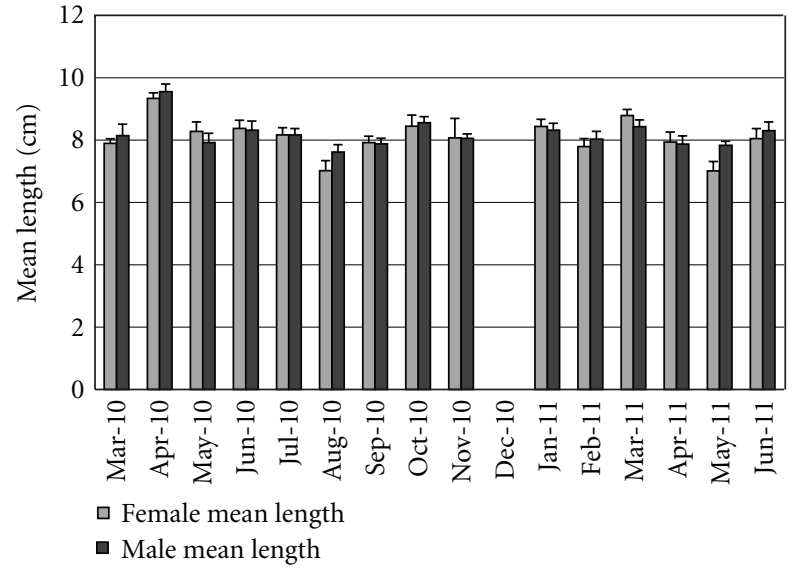

Figure 2: Mean length ( \pm S.D.) of female and male Mya arenaria sampled at Bannow Bay from March 2010 to June 2011.

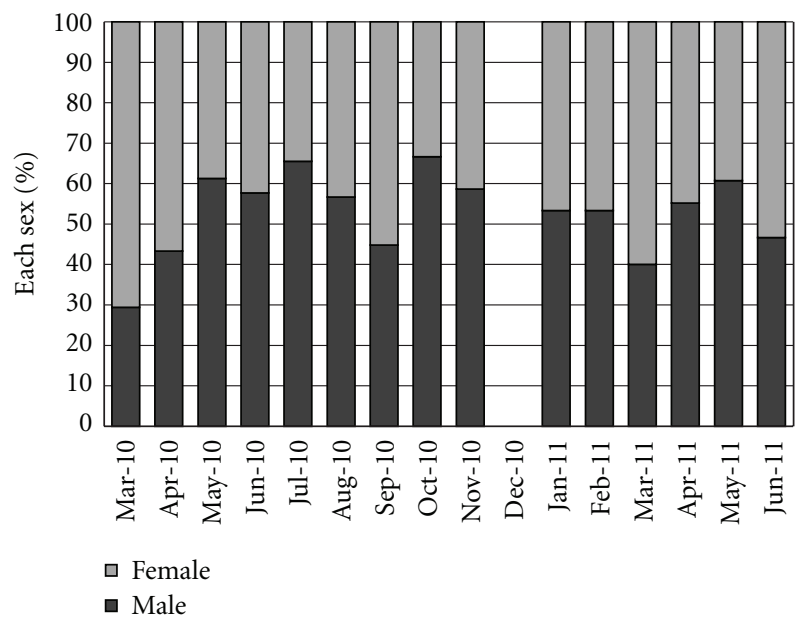

Figure 3: Sex ratio of Mya arenaria sampled at Bannow Bay over study period.

was not statistically significant when using a $t$-test $(t=0.53$, $d f=28, P>0.1)$. Only measurements of undamaged shells were included in the results.

\subsection{Histology}

3.2.1. Sex Ratio. Of the softshell clams examined, 199 (46\%) were female, 229 (53\%) were male, and four (1\%) were immature or the sex could not be determined (Figure 3). A Chi-squared $\left(\chi^{2}\right)$ was used to analyse sex ratios. The overall female:male sex ratio of $1: 1.15$ did not show a significant divergence from a $50: 50$ ratio $\left(\chi^{2}=2.57, d f=1, P>0.05\right)$. Within months, it was revealed that there was no statistically significant divergence from the 50:50 ratio of sexes $\left(\chi^{2}=\right.$ $0.133, d f=1, P>0.05$ to $\left.\chi^{2}=2.882, d f=1, P>0.05\right)$, though the closest to showing a significant divergence was the October 2010 sample, with 10 female and 20 male $M$. arenaria $\left(\chi^{2}=3.333, d f=1, P>0.05\right)$. 




FIGURE 4: Stages of gametogenesis observed in female clams over the study period.

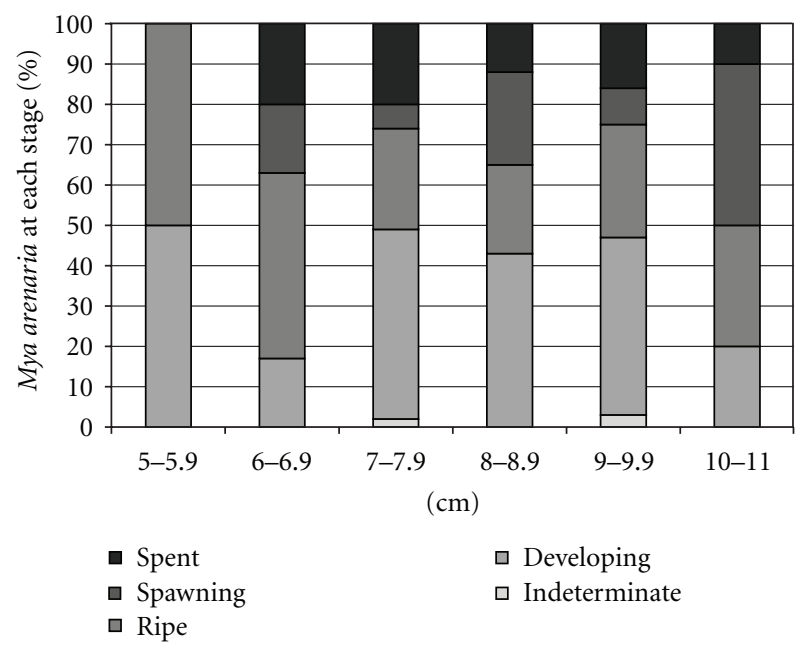

Figure 5: Relationship between female Mya arenaria length and stage of gametogenesis.

\subsubsection{Sexual Cycle}

Female. During the course of the study, all five of the stages of gametogenesis described by Brousseau [12] were observed. In 2010, the sampled female $M$. arenaria showed a less defined cycle than the male individuals, with development, ripening and spawning taking place from March to October (Figure 4). Fifty percent of individuals were spent in May 2010, following a large number (76\%) ripe in March, and $41 \%$ spawning in April. The percentage of females developing rose from March to July 2010, with all individuals either ripe or spawning by August 2010 (Figure 4). The majority of spawning individuals were present in September (62\%), with all spawning completed by November 2010. October and November samples contained the highest percentage of spent females, at $70 \%$ and $67 \%$, respectively, with some indifferent individuals also present (10\%).



Figure 6: Relationship between female Mya arenaria weight and stage of gametogenesis.

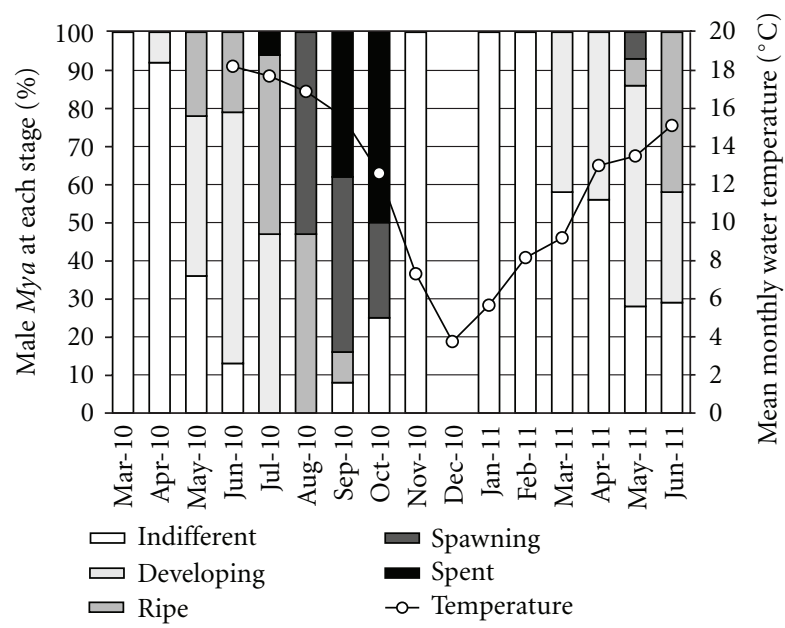

FIGURE 7: Stages of gametogenesis observed in male clams over the study period.

In 2011 most females were developing over the winter months of January and February ( 90\%), with some spent individuals present $(\sim 10 \%)$. Female $M$. arenaria began ripening in March 2011, similar to 2010, but at a much lower percentage $(39 \%)$. The majority of individuals $(\sim 60 \%)$ were developing from March to June 2011, with some at the ripe stage $(\sim 30 \%)$ but none were spawning, in contrast to the same period in 2010. There were spent females present in April, May, and June of 2011, and individuals of indifferent stage present in April (9\%).

Male. In the collected samples, all male $M$. arenaria were indifferent in March 2010 (100\%), which steadily decreased until June (13\%) (Figure 7). Development of the male gonads began to take place in April (8\%) and spawning was observed for the final time in October 2010. The number of developing individuals rose to $66 \%$ in June and $47 \%$ in July 2010. Ripe individuals were first present in May (22\%), and by August all males were either ripe (47\%) or spawning 


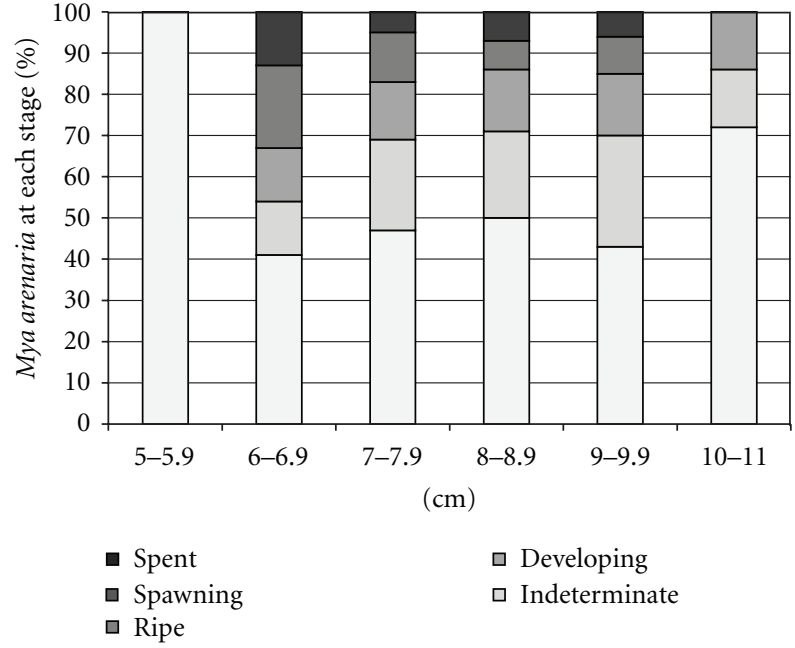

FIGURE 8: Relationship between male Mya arenaria length and stage of gametogenesis.

(53\%). Spawning was completed by November 2010, with the majority of individuals spent in September (38\%) and October (50\%) samples. All males collected from November 2010 to February 2011 were in the resting indifferent stage, with development beginning earlier in March 2011, as compared to the previous year, when developing individuals were not detected until April. Ripe individuals were present in May 2011, similar to the previous year, though some spawning individuals were present in this month, compared to a lack of spawning individuals until August in 2010. There were a higher number of indifferent individuals present in June 2011 (29\%) as opposed to June 2010 (13\%).

The smallest reproducing female and males sampled were $5.1 \mathrm{~cm}(17.8 \mathrm{~g})$ and $6.1 \mathrm{~cm}(29.0 \mathrm{~g})$, respectively. The only immature clam collected was $2.6 \mathrm{~cm}$ in length, and $3.1 \mathrm{~g}$ in weight.

3.2.3. Disease. Screening of the histological sections of the visceral mass, gill, and mantle of sampled Mya arenaria revealed no parasites or pathological indications of disease, such as hematopoietic neoplasia, in any of the individuals sampled in Bannow Bay over the study period.

3.3. Temperature. The mean monthly temperature recorded by the Stowaway Tidbit Temperature Logger, underwater, at Bannow Bay was highest in June 2010 at $18^{\circ} \mathrm{C}$ and decreased each subsequent month to $3^{\circ} \mathrm{C}$ in December 2010 (Table 1). The highest recorded temperature points in 2010 were $27.97^{\circ} \mathrm{C}$ on June 26 th and $27.31^{\circ} \mathrm{C}$ on July 12 th, and the lowest was $-1.66^{\circ} \mathrm{C}$ on December 24th and 25th. The lowest water temperature recorded in 2011 was recorded at $-0.44^{\circ} \mathrm{C}$ on 29 th January. Mean monthly water temperatures rose from $5.66^{\circ} \mathrm{C}$ in January 2011 to $15.1^{\circ} \mathrm{C}$ in June, peaking at $26.4^{\circ} \mathrm{C}$ on 3 rd June 2011 (Table 1 ).

Air temperature readings at Johnstown Castle from January 2008 to July 2011 showed a decrease in the monthly minimum temperatures recorded during the winter months, from $4.4^{\circ} \mathrm{C}$ in January 2008 to $2.3^{\circ} \mathrm{C}$ in January 2009 , and
TABLE 1: The mean, minimum, and maximum monthly water temperatures and degree days per month, recorded by a continuous temperature monitor in Bannow Bay from June 2010 to June 2011.

\begin{tabular}{lllll}
\hline Month & $\begin{array}{l}\text { Mean } \\
\text { temperature }\end{array}$ & $\begin{array}{l}\text { Minimum } \\
\text { temperature }\end{array}$ & $\begin{array}{l}\text { Maximum } \\
\text { temperature }\end{array}$ & $\begin{array}{l}\text { Degree } \\
\text { days/month }\end{array}$ \\
\hline Jun-10 & 18.21 & 10.34 & 27.97 & 546.3 \\
Jul-10 & 17.7 & 13.51 & 27.31 & 548.7 \\
Aug-10 & 16.89 & 9.48 & 26.32 & 523.59 \\
Sep-10 & 15.59 & 8.62 & 24.06 & 467.7 \\
Oct-10 & 12.59 & 5.73 & 18.21 & 390.29 \\
Nov-10 & 7.31 & -1.35 & 16.43 & 219.3 \\
Dec-10 & 3.75 & -1.66 & 8.33 & 116.25 \\
Jan-11 & 5.66 & -0.44 & 9.48 & 175.46 \\
Feb-11 & 8.16 & 4.6 & 11.8 & 228.48 \\
Mar-11 & 9.2 & 4.9 & 16 & 285.2 \\
Apr-11 & 13 & 8 & 22.2 & 403 \\
May-11 & 13.5 & 8.6 & 20.6 & 418.5 \\
Jun-11 & 15.1 & 10.3 & 26.4 & 453 \\
\hline
\end{tabular}



FIGURE 9: Relationship between male Mya arenaria weight and stage of gametogenesis.

$-0.15^{\circ} \mathrm{C}$ in December 2010. The mean monthly winter temperatures also showed a decrease during this time, from $6.9^{\circ} \mathrm{C}$ in January 2008 to $4.9^{\circ} \mathrm{C}$ in January 2009 , and $2.2^{\circ} \mathrm{C}$ in December 2010 (Figure 10).

In 2008 the mean monthly air temperatures at Johnstown Castle rose from $6.9^{\circ} \mathrm{C}$ and $6.5^{\circ} \mathrm{C}$ in January and February, respectively, to $15.4^{\circ} \mathrm{C}$ in July and August, peaking at $18.5^{\circ} \mathrm{C}$ in July 2008. Mean monthly air temperatures fell to $4.9^{\circ} \mathrm{C}$ in January 2009, and increased to $15.2^{\circ} \mathrm{C}$ in August, with the maximum temperature of 2009 recorded at $18^{\circ} \mathrm{C}$ in August. In 2010 the mean monthly air temperature of $3.5^{\circ} \mathrm{C}$ was recorded in January, rising to $16.5^{\circ} \mathrm{C}$ in July, and peaking at $19.2^{\circ} \mathrm{C}$. In 2011 the mean monthly air temperatures at Johnstown Castle were $1.7^{\circ} \mathrm{C}$ warmer, on average, from January to June, than the same months in 2010. The 


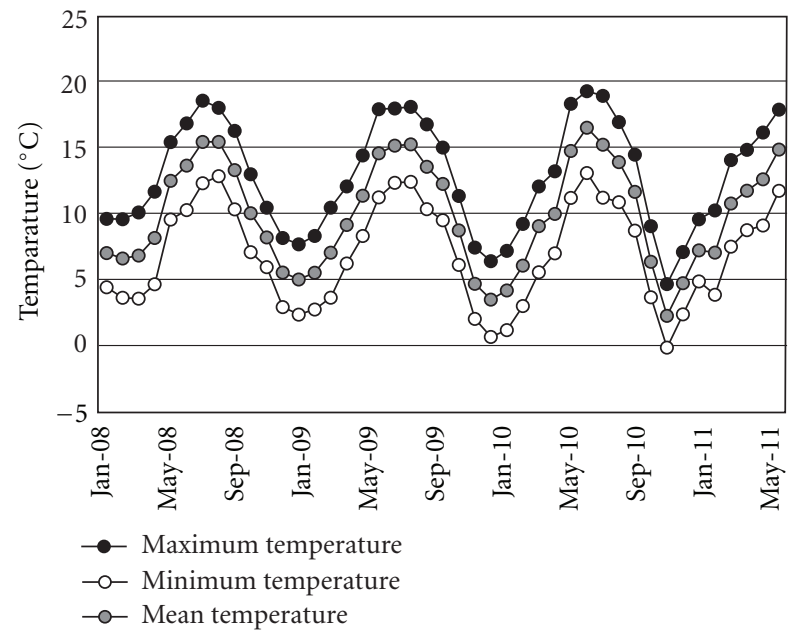

Figure 10: Air temperature reading for Johnstown Castle, January 2008 to July 2011, showing mean, maximum, and minimum temperature for each month.

maximum temperature recorded in 2011 up to the end of the field trial was $17.8^{\circ} \mathrm{C}$ in July (Figure 10).

\section{Discussion}

Of the sampled Mya arenaria, the average length of all individuals was $8.17 \pm 0.18 \mathrm{~cm}$, with the shortest measuring $2.6 \mathrm{~cm}$ and the longest $11.5 \mathrm{~cm}$. Previous studies in North American [33] and European [20] waters have revealed maximum lengths of individuals between 10 and $17 \mathrm{~cm} \mathrm{[34,}$ 35]. Past work has revealed that softshell clams smaller than $2 \mathrm{~cm}$ in length are usually immature, with indistinguishable gonads $[12,24]$. First reproduction usually occurs at a size of $2-5 \mathrm{~cm}$ in length $[6,36]$ which, depending on environmental conditions, can mean the individual is anything from 1 to 4 years of age [6]. Newell and Hidu [11] suggested that the size of the individual is more important than age when it comes to the initiation of a spawning event. Data collected in the present study correlate with this, in that the smallest reproducing female and male were 5.1 and $6.1 \mathrm{~cm}$, respectively. The sex of the smallest clam sampled $(2.6 \mathrm{~cm})$ was not discernible as the clam was immature.

The overall female:male sex ratio of $1: 1.15$ in the present study did not show a significant divergence from the 50:50 ratio previously described in Denmark [19] and Oslofjord, Norway [20], and on north American coasts in Massachusetts and Connecticut [12, 24], in Maryland [37], and in Washington [32]. There was no evidence of hermaphroditism or protandry in the present study, in keeping with recordings of low incidences of hermaphroditism in past studies [19, 24, 38]. All stages of gametogenic development of $M$. arenaria previously described by Brousseau [12] were observed over the period of sampling. Mya arenaria matured over the summer months of 2010, with both sexes either ripe or spawning by August, similar in timing to the spawning period recorded in New England [13], in Massachusetts, USA
$[39,40]$, in Denmark [41], and in the Dutch Wadden Sea [17].

Previous studies of $M$. arenaria in both North America and continental Europe have shown that softshell clams can spawn either once or twice during one year, with the majority of spawning taking place during June, July, and August $[6,12$, 35]. The data from the present study demonstrated that male Mya arenaria of Bannow Bay had one spawning period at the end of summer 2010. These data are in keeping with previous observations in the north east Atlantic in the Black Sea [15], on the west coast of Sweden [18], on the east coast of Denmark [19], and in the Wadden Sea [16, 17]. The female $M$. arenaria of Bannow Bay show a less tightly defined spawning period than the males, with spawning individuals recorded from March to October, and peaks in spawning taking place in April, June, and August/September 2010. However, all female individuals were either ripe or spawning in August 2010, with a large percentage in these stages in September, and most individuals spent in October and November. Based on the data collected at Bannow Bay, Ireland, and previous research across the North Atlantic, it would seem that the reproductive cycle of Mya arenaria is affected by more than just latitudinal distribution of individuals $[12,42]$.

In eastern Atlantic waters the majority of spawning periods have been recorded in the summer months of May and June (Table 2). Where $M$. arenaria were recorded as spawning biannually, in Oslofjord, Norway, and S. E. England, the second spawning took place in or around September. In 2010, the present study revealed spawning at a similar time of March to July for female softshell clams, and August to October for both female and male clams (Table 3). The less tightly defined spawning period of female $M$. arenaria compared to male individuals has not been recorded previously in European waters, and was not repeated in 2011, when no spawning had taken place in female $M$. arenaria by June, when the field study concluded.

Environmental conditions including food availability and temperature have been shown to affect gametogenesis and spawning of $M$. arenaria [24]. It is currently unknown whether a "critical" water temperature is more important at a certain point in gonadal development, to progress maturation, or to begin the spawning event itself $[24,43]$, though Belding [40] concluded that the degree of maturation of $M$. arenaria is dependent on the number of days the water temperature remains in the desired range for gamete formation. It is generally considered that spawning of $M$. arenaria begins when water temperature rises to $10^{\circ} \mathrm{C}[4,44]$, though this can depend on the area, as a spawning peak was recorded at 4-6 ${ }^{\circ} \mathrm{C}$ in Massachusetts [24] while Belding [40] reported a spawning peak at $22^{\circ} \mathrm{C}$ in the same area. When $M$. arenaria are forced to spawn in culture, water temperature needs to reach 22 to $24^{\circ} \mathrm{C}$ before spawning begins [45]. The male $M$. arenaria of this study began spawning in August 2010, which had an average daily water temperature of $16.9^{\circ} \mathrm{C}$. However, the two preceding months of June and July had average daily water temperatures of 18.2 and $17.7^{\circ} \mathrm{C}$, respectively, with $22^{\circ} \mathrm{C}$ and $24^{\circ} \mathrm{C}$ first recorded in late May 2010. The majority of spawning of female $M$. arenaria also took place in August and September 2010, with a small group spawning 
TABLE 2: The timing of spawning seasons, by latitude, of European Mya arenaria reported in the literature.

\begin{tabular}{|c|c|c|c|c|c|}
\hline Area & Latitude & Tidal level & Spawning & Month & Authors \\
\hline Oslofjord, Norway & $\begin{array}{l}59^{\circ} 91^{\prime} \mathrm{N} \\
10^{\circ} 37^{\prime} \mathrm{E}\end{array}$ & Intertidal & Biannual & June and September & Winther and Gray, 1985 [20] \\
\hline West coast of Sweden & $\begin{array}{l}57^{\circ} 37^{\prime} \mathrm{N} \\
35^{\circ} 51^{\prime} \mathrm{E}\end{array}$ & Intertidal & Annual & June/July & $\begin{array}{c}\text { Möller and Rosenberg, } 1983 \\
\text { [18] }\end{array}$ \\
\hline Wadden Sea & $\begin{array}{c}55^{\circ} 00^{\prime} \mathrm{N} \\
6^{\circ} 7^{\prime} \mathrm{W}\end{array}$ & Intertidal & Annual & May/June & Günther, 1992 [16] \\
\hline Dutch Wadden Sea & $\begin{array}{c}55^{\circ} 00^{\prime} \mathrm{N} \\
6^{\circ} 7^{\prime} \mathrm{W}\end{array}$ & Subtidal and Intertidal & Annual & July-November & Cardoso et al., 2009 [17] \\
\hline Denmark & $\begin{array}{l}55^{\circ} 55^{\prime} \mathrm{N} \\
12^{\circ} 0^{\prime} \mathrm{E}\end{array}$ & Subtidal & Annual & May/June & Munch-Petersen, 1973 [19] \\
\hline S.E. Ireland & $\begin{array}{l}52^{\circ} 13^{\prime} \mathrm{N} \\
06^{\circ} 47^{\prime} \mathrm{W}\end{array}$ & Intertidal & Annual & August/September & Current paper \\
\hline S.E. England & $\begin{array}{l}50^{\circ} 37^{\prime} \mathrm{N} \\
4^{\circ} 25^{\prime} \mathrm{W}\end{array}$ & Intertidal & Biannual & $\begin{array}{l}\text { March and late } \\
\text { Summer }\end{array}$ & Warwick and Price, 1975 [21] \\
\hline Black Sea & $\begin{array}{l}42^{\circ} 30^{\prime} \mathrm{N} \\
35^{\circ} 00^{\prime} \mathrm{E}\end{array}$ & $\mathrm{N} / \mathrm{A}$ & Annual & Late May & Began, 1979 [15] \\
\hline
\end{tabular}

TABLE 3: The number of female and male Mya arenaria individuals present each month, in the five stages of gametogenesis.

\begin{tabular}{|c|c|c|c|c|c|c|c|c|c|c|}
\hline & \multicolumn{2}{|c|}{ Indeterminate } & \multicolumn{2}{|c|}{ Developing } & \multicolumn{2}{|c|}{ Ripe } & \multicolumn{2}{|c|}{ Spawning } & \multicolumn{2}{|c|}{ Spent } \\
\hline & $\mathrm{F}$ & M & $\mathrm{F}$ & M & $\mathrm{F}$ & $\mathrm{M}$ & $\mathrm{F}$ & M & $\mathrm{F}$ & $\mathrm{M}$ \\
\hline Mar-10 & & 5 & 2 & & 9 & & 1 & & & \\
\hline Apr-10 & & 12 & 4 & 1 & 6 & & 7 & & & \\
\hline May-10 & & 7 & 4 & 8 & & 4 & 2 & & 6 & \\
\hline Jun-10 & & 2 & 4 & 10 & 3 & 4 & 4 & & & \\
\hline Jul-10 & & & 4 & 9 & 4 & 9 & 1 & & 1 & 1 \\
\hline Aug-10 & & & & & 9 & 8 & 4 & 9 & & \\
\hline Sep-10 & & 1 & & & 3 & 1 & 10 & 6 & 3 & 5 \\
\hline Oct-10 & 1 & 5 & & & 1 & & 1 & 5 & 7 & 10 \\
\hline Nov-10 & 1 & 17 & 3 & & & & & & 8 & \\
\hline Jan-11 & & 16 & 13 & & & & & & 1 & \\
\hline Feb-11 & & 16 & 12 & & & & & & 2 & \\
\hline Mar-11 & & 7 & 11 & 5 & 7 & & & & & \\
\hline Apr-11 & 1 & 9 & 6 & 7 & 3 & & & & 2 & \\
\hline May-11 & & 5 & 7 & 10 & 3 & 1 & & 1 & 1 & \\
\hline Jun-11 & & 4 & 9 & 4 & 6 & 6 & & & 1 & \\
\hline
\end{tabular}

in May. In 2011, water temperatures first rose to $10^{\circ} \mathrm{C}$ in the last week of February, and male development began in early March. Female development was in progress during the winter months, but ripe individuals were first detected in March 2011. The critical spawning temperature of $22^{\circ} \mathrm{C}$ was first recorded in 2011 on 2 nd June. The critical upper temperature of $28^{\circ} \mathrm{C}[4,6]$ was never reached in the waters of Bannow Bay in 2010, though a peak of $27^{\circ} \mathrm{C}$ was recorded in July 2010 for a short period of time.

The winters of 2009/2010 and 2010/2011 were exceptionally cold in Ireland, with air temperatures decreasing to $-17^{\circ} \mathrm{C}$ in Northern areas in January 2011 [30]. Air temperature data, collected at Johnstown Castle $(20 \mathrm{~km}$ from Bannow Bay) for the period January 2008 to July 2011, reveal that the lowest recorded temperatures dropped each winter from $3^{\circ} \mathrm{C}$ in March 2008, to $2.34^{\circ} \mathrm{C}$ in January 2009 , $0.65^{\circ} \mathrm{C}$ in January 2011, and to $-0.2^{\circ} \mathrm{C}$ in December 2010 (Figure 10). Unusually cold intervals similar to this have lead to mass mortalities of bivalve species, and contraction of species range in the past [46]. A disparity in gametogenic development timing between the sexes may be a critical factor reducing recruitment in the species, as it results in less overlap of months where both sexes are spawning simultaneously. In 2010, female and male $M$. arenaria of Bannow Bay were spawning synchronously in the months of August, September, and October, while the gametes released by female individuals from March to July 2010 would have remained unfertilised.

Following the period of cold winters, air temperature readings from Johnstown Castle reveal monthly mean temperatures were greater in 2011 compared to 2010, from January to May (Figure 10). In the present study, the effects 
of two unusually cold winters, followed by a warmer than average spring, would seem to have affected the timing of development in M. arenaria individuals in 2011, compared to 2010. In the males of the species, the variable temperatures appear to have advanced the progression of gonad development, with 42 and $44 \%$ of males developing in March and April 2011, though none or few individuals were developing in the same months in the previous year. Ripe males were first recorded in May of each year, with spawning taking place in 2010 in August, though spawning was observed as early as May in 2011. In contrast, the development of female M. arenaria would seem to have been inhibited in 2011, with the majority of individuals still developing in March, compared to the majority of females already being ripe in March 2010. Also, though spawning individuals were present from March in 2010, by June 2011 only ripe individuals were still present in the sample, with many (56\%) still developing. Overall, the cold winters followed by a warmer than average spring appeared to have accelerated gametogenesis in males in 2011, compared to 2010, and had the opposite effect in female Mya arenaria. This asynchronous spawning may be a critical factor reducing recruitment in the species if climatic variability continues and male and female Mya arenaria continue to spawn at different times.

No disease or pathogens have been observed in the Irish Sea $M$. arenaria, despite the fact that other bivalves such as Cerastoderma edule collected monthly in the same area have revealed a heavy prevalence of trematodes, neoplasia and Nematopsis spp. (Morgan, pers comm). To date, only low levels of disease or pathogens has been reported in Mya arenaria on European shores [47], despite a number of diseases and parasites being present in the $M$. arenaria populations of North America, particularly hematopoietic neoplasia, which was not observed in this study [48-53]. This could be due to a lower density of these animals, than in the intensively cultured areas of North America [54].

In summary, the Mya arenaria of Bannow Bay of south east Ireland matured over the summer months of 2010, with both sexes either ripe or spawning by August in a single spawning episode, and all spawning being completed by November. Gametogenic development of female M. arenaria would seem to be inhibited in 2011, compared to 2010, while development of male clams has been advanced. Progression of developmental stages suggests that a discrepancy between the sexes spawning events could occur, affecting recruitment in Bannow Bay M. arenaria.

\section{Acknowledgment}

This project was part-funded by the Ireland Wales Programme 2007-2013 INTERREG 4A European Regional Development Fund.

\section{References}

[1] R. Lasota, H. Hummel, and M. Wolowicz, "Genetic diversity of European populations of the invasive soft-shell clam Mya arenaria (Bivalvia)," Journal of the Marine Biological Association of the United Kingdom, vol. 84, no. 5, pp. 1051-1056, 2004.
[2] B. F. Beal, "Adding value to live, commercial size soft-shell clams (Mya arenaria L.) in Maine, USA: results from repeated, small-scale, field impoundment trials," Aquaculture, vol. 210, no. 1-4, pp. 119-135, 2002.

[3] L. B. Connell, S. P. MacQuarrie, B. M. Twarog, M. Iszard, and V. M. Bricelj, "Population differences in nerve resistance to paralytic shellfish toxins in softshell clam, Mya arenaria, associated with sodium channel mutations," Marine Biology, vol. 150, no. 6, pp. 1227-1236, 2007.

[4] S. Weston and J. K. Buttner, "Softshell clam culture: basic biology and general culture considerations," NRAC Publication 201, 2010.

[5] Y. Zaitsev and V. Mamaev, Marine Biological Diversity in the Black Sea, United Nations Publications, New York, NY, USA, 1997.

[6] M. Strasser, "Mya arenaria - an ancient invader of the North Sea coast," Helgoland Marine Research, vol. 52, no. 3, pp. 309324, 1999.

[7] A. Conde, J. Novais, and J. Domínguez, "Southern limit of distribution of the soft-shell clam Mya arenaria on the Atlantic East Coast," Biological Invasions, vol. 12, no. 3, pp. 429-432, 2010.

[8] L. Zwarts and J. Wanink, "Siphon size and burying depth in deposit- and suspension-feeding benthic bivalves," Marine Biology, vol. 100, no. 2, pp. 227-240, 1989.

[9] N. C. Eno, R. A. Clark, and W. G. Sanderson, Non-Native Marine Species in British Waters: A Review and Directory, Joint Nature Conservation Committee, 1997.

[10] R. M. O'Riordan, C. Moriarty, and D. Murray, "The accidental introduction of marine animals into Ireland," in Biological Invaders: The Impact of Exotic Species, pp. 95-106, 2002.

[11] C. Newell and H. Hidu, Species Profiles: Life Histories and Environmental Requirements of Coastal Fish and Invertebrates (North Atlantic): Softshell Clam. [Mya arenaria], Maine Shellfish Research and Development, Damariscotta (USA), Maine Shellfish Research and Development, Damariscotta (USA); Maine University, Orono (USA), Department of Animal and Veterinary Sciences, 1986.

[12] D. Brousseau, "A comparative study of the reproductive cycle of the soft-shell clam, Mya arenaria in Long Island Sound," Journal of Shellfish Research, vol. 6, no. 1, pp. 7-16, 1987.

[13] J. Ropes and A. Stickney, "Reproductive cycle of Mya arenaria in New England," Biological Bulletin, vol. 128, no. 2, pp. 315327, 1965.

[14] H. T. Pfitzenmeyer, "Annual cycle of gametogenesis of the soft-shelled clam, Mya arenaria, at Solomons, Maryland," Chesapeake Science, vol. 6, no. 1, pp. 52-59, 1965.

[15] Y. P. Began, "Reproduction and growth of Mya arenaria in the Black Sea," Biologija Morja, vol. 6, pp. 70-72, 1979.

[16] C. P. Günther, "Settlement and recruitment of Mya arenaria L. in the Wadden Sea," Journal of Experimental Marine Biology and Ecology, vol. 159, no. 2, pp. 203-215, 1992.

[17] J. F. M. F. Cardoso, J. I. Witte, and H. W. van der Veer, "Differential reproductive strategies of two bivalves in the Dutch Wadden Sea," Estuarine, Coastal and Shelf Science, vol. 84, no. 1, pp. 37-44, 2009.

[18] P. Möller and R. Rosenberg, "Recruitment, abundance and production of Mya arenaria and Cardium edule in marine shallow waters, western Sweden," Ophelia, vol. 22, no. 1, pp. 33-55, 1983.

[19] S. Munch-Petersen, "An investigation of a population of the soft clam (Mya arenaria L.) in a Danish estuary," Fiskeridirektoratets Skrifter. Serie Havunders Kelser, vol. 3, pp. 47-73, 1973. 
[20] U. Winther and J. Gray, "The biology of Mya arenaria (Bivalvia) in the eutrophic inner Oslofjord," Sarsia, vol. 70, no. 1, pp. 1-9, 1985.

[21] R. Warwick and R. Price, "Macrofauna production in an estuarine mud-flat," Journal of the Marine Biological Association of the UK, vol. 55, no. 1, pp. 1-18, 1975.

[22] S. Gauthier-Clerc, J. Pellerin, C. Blaise, and F. Gagné, "Delayed gametogenesis of Mya arenaria in the Saguenay fjord (Canada): a consequence of endocrine disruptors?" Comparative Biochemistry and Physiology, vol. 131, no. 4, pp. 457-467, 2002.

[23] I. Kröncke, H. Reiss, J. D. Eggleton et al., "Changes in North Sea macrofauna communities and species distribution between 1986 and 2000," Estuarine, Coastal and Shelf Science, vol. 94, no. 1, pp. 1-15, 2011.

[24] D. Brousseau, "Spawning cycle, fecundity, and recruitment in a population of soft-shell clam, Mya arenaria, from Cape Ann, Massachusetts," Fishery Bulletin, vol. 76, no. 1, pp. 155-166, 1978.

[25] C. J. M. Philippart, R. Anadón, R. Danovaro et al., "Impacts of climate change on European marine ecosystems: observations, expectations and indicators," Journal of Experimental Marine Biology and Ecology, vol. 400, no. 1-2, pp. 52-69, 2011.

[26] V. Matozzo and M. Marin, "Bivalve immune responses and climate changes: is there a relationship?" Information Systems Journal, vol. 8, pp. 70-77, 2011.

[27] D. S. Wethey, S. A. Woodin, T. J. Hilbish, S. J. Jones, F. P. Lima, and P. M. Brannock, "Response of intertidal populations to climate: effects of extreme events versus long term change," Journal of Experimental Marine Biology and Ecology, vol. 400, no. 1-2, pp. 132-144, 2011.

[28] K. Hiscock, A. Southward, I. Tittley, and S. Hawkins, "Effects of changing temperature on benthic marine life in Britain and Ireland," Aquatic Conservation, vol. 14, no. 4, pp. 333-362, 2004.

[29] J. H. Christensen, B. Hewitson, A. Busuioc et al., "Regional climate projections," Climate Change 2007: The Physical Science Basis. Contribution of Working Group I to the Fourth Assessment Report of the Intergovernmental Panel on Climate Change, Cambridge University Press, Cambridge, UK, 2007.

[30] MetEireann, Exceptional Weather Events, 2010, http://www .met.ie/climate-ireland/weather-events/Winter2009-10.pdf.

[31] S. K. Malham, E. Cotter, S. O'Keeffe et al., "Summer mortality of the Pacific oyster, Crassostrea gigas, in the Irish Sea: the influence of temperature and nutrients on health and survival," Aquaculture, vol. 287, no. 1-2, pp. 128-138, 2009.

[32] R. Porter, "Reproductive cycle of the soft-shell clam, Mya arenaria, at Skagit Bay, Washington," Fishery Bulletin, vol. 72, no. 3, pp. 648-656, 1974.

[33] D. J. Brousseau, "Analysis of growth rate in Mya arenaria using the Von Bertalanffy equation," Marine Biology, vol. 51, no. 3, pp. 221-227, 1979.

[34] D. Cowles, Mya (Arenomya) arenaria Linnaeus, 1758, 2007, http://www.wallawalla.edu.

[35] A. N. Cohen, The Exotics Guide: Non-Native Marine Species of the North American Pacific Coast, Center for Research on Aquatic Bioinvasions, Richmond, Calif, USA; San Francisco Estuary Institute, Oakland, Calif, USA, 2011, http:// www.exoticsguide.org/.

[36] DFO, "Assessment of softshell clam stocks in Quebec's coastal waters in 2010," DFO Canadian Science Advisory Secretariat Report 2011/022, DFO, 2011.

[37] W. N. Shaw, "Seasonal gonadal changes in female soft-shell clams, Mya arenaria, in the Tred Avon River, Maryland,"
Proceedings of the National Shellfisheries Association, vol. 53, pp. 121-132, 1962.

[38] W. R. Coe and H. J. Turner Jr., "Development of the gonads and gametes in the soft shell clam (Mya arenaria)," Journal of Morphology, vol. 62, no. 1, pp. 91-111, 1938.

[39] J. Stevenson, "Report of JR Stevenson upon observations and experiments on mollusks in Essex County during 1906," Arkansas Game and Fish Commission, pp. 68-96, 1906.

[40] D. L. Belding, The Soft-Shelled Clam Fishery of Massachusetts, Marine Fisheries Series, 1930.

[41] G. Thorson, "Reproduction and larval development of Danish marine bottom invertebrates; with special reference to the planktonic larvae in the Sound (Øresund)," Meddelelser fra Kommissionen for Danmarks Fiskeri- og Havundersøgelser. Serie Plankton, vol. 4, no. 1, pp. 1-523, 1946.

[42] C. R. Newell and H. Hidu, "The effects of sediment type on growth rate and shell allometry in the soft shelled clam Mya arenaria L," Journal of Experimental Marine Biology and Ecology, vol. 65, no. 3, pp. 285-295, 1982.

[43] V. L. Loosanoff and H. C. Davis, "Spawning of oysters at low temperatures," Science, vol. 111, no. 2889, pp. 521-522, 1950.

[44] T. C. Nelson, "On the distribution of critical temperatures for spawning and for ciliary activity in bivalve molluscs," Science, vol. 67, no. 1730, pp. 220-221, 1928.

[45] J. K. Buttner and S. Weston, "Softshell clam culture: hatchery phase, broodstock cat through seed production," NRAC Publication 202, 2010.

[46] D. Crisp, "The effects of the severe winter of 1962-63 on marine life in Britain," Journal of Animal Ecology, vol. 33, no. 1, pp. 165-210, 1964.

[47] M. Strasser, M. Walensky, and K. Reise, "Juvenile-adult distribution of the bivalve Mya arenaria on intertidal flats in the Wadden Sea: why are there so few year classes?" Helgoland Marine Research, vol. 53, no. 1, pp. 45-55, 1999.

[48] P. M. Earle and F. D. Crisley, "Isolation and characterization of Vibrio parahaemolyticus from Cape Cod soft shell clams (Mya arenaria)," Journal of Applied Microbiology, vol. 29, no. 5, pp. 635-640, 1975.

[49] M. Gibbons and W. Blogoslawski, "Predators, pests, parasites, and diseases," in Clam Mariculture in North America, pp. 167200, Elsevier, Amsterdam, The Netherlands, 1989.

[50] H. Hidu and C. Newell, "Culture and ecology of the softshelled clam, Mya arenaria," in Clam Mariculture in North America, Elsevier, Amsterdam, The Netherlands, 1989.

[51] D. F. Leavitt, J. McDowell Capuzzo, R. M. Smolowitz, D. L. Miosky, B. A. Lancaster, and C. L. Reinisch, "Hematopoietic neoplasia in Mya arenaria: prevalence and indices of physiological condition," Marine Biology, vol. 105, no. 2, pp. 313$321,1990$.

[52] S. M. McLaughlin and M. Faisal, "A comparison of diagnostic assays for detection of Perkinsus spp. in the softshell clam Mya arenaria," Aquaculture, vol. 172, no. 1-2, pp. 197-204, 1999.

[53] C. F. Dungan, R. M. Hamilton, K. L. Hudson, C. B. McCollough, and K. S. Reece, "Two epizootic diseases in Chesapeake Bay commercial clams, Mya arenaria and Tagelus plebeius," Diseases of Aquatic Organisms, vol. 50, no. 1, pp. 67-78, 2002.

[54] T. Renault and B. Novoa, "Viruses infecting bivalve molluscs," Aquatic Living Resources, vol. 17, no. 4, pp. 397-409, 2004. 

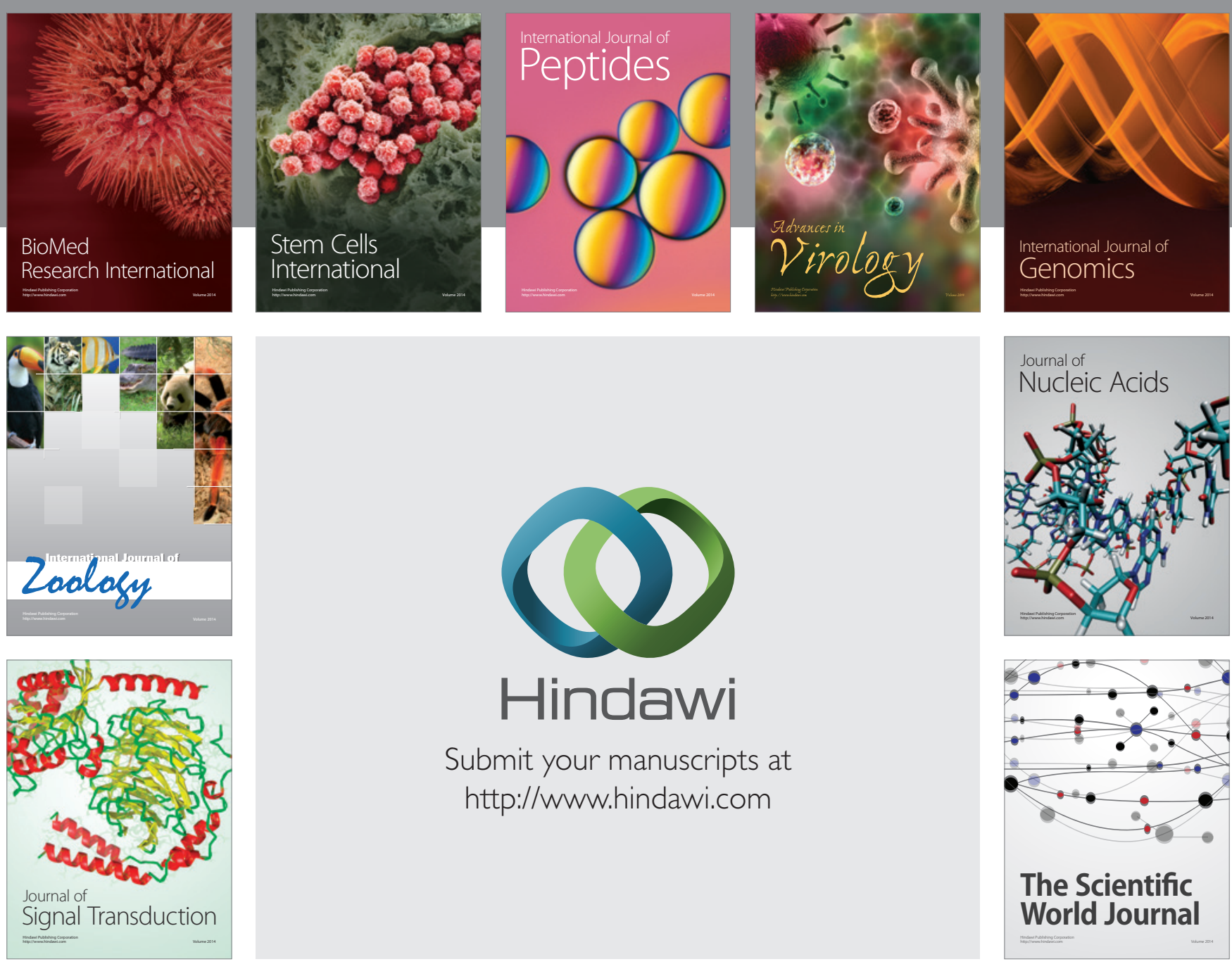

Submit your manuscripts at

http://www.hindawi.com
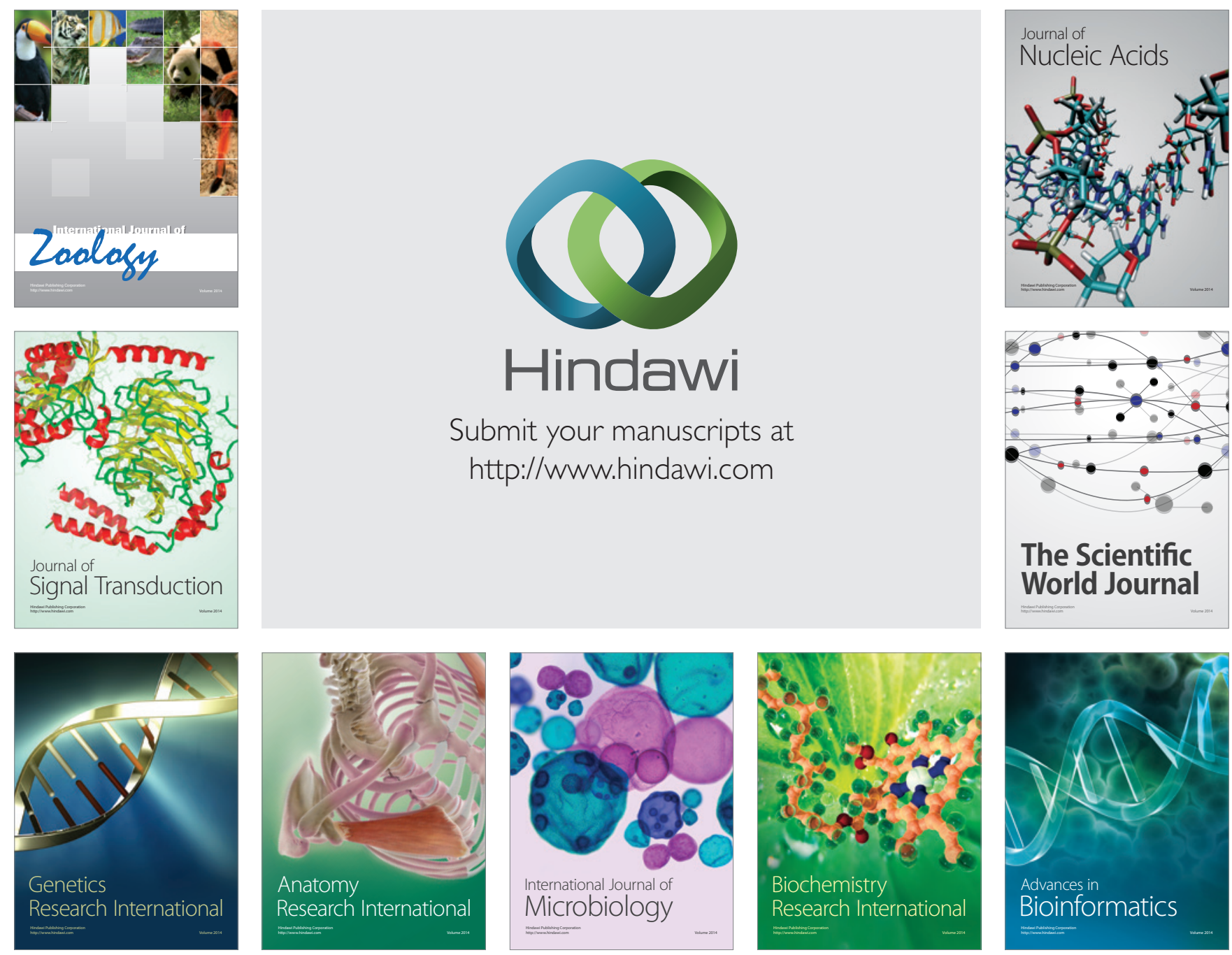

The Scientific World Journal
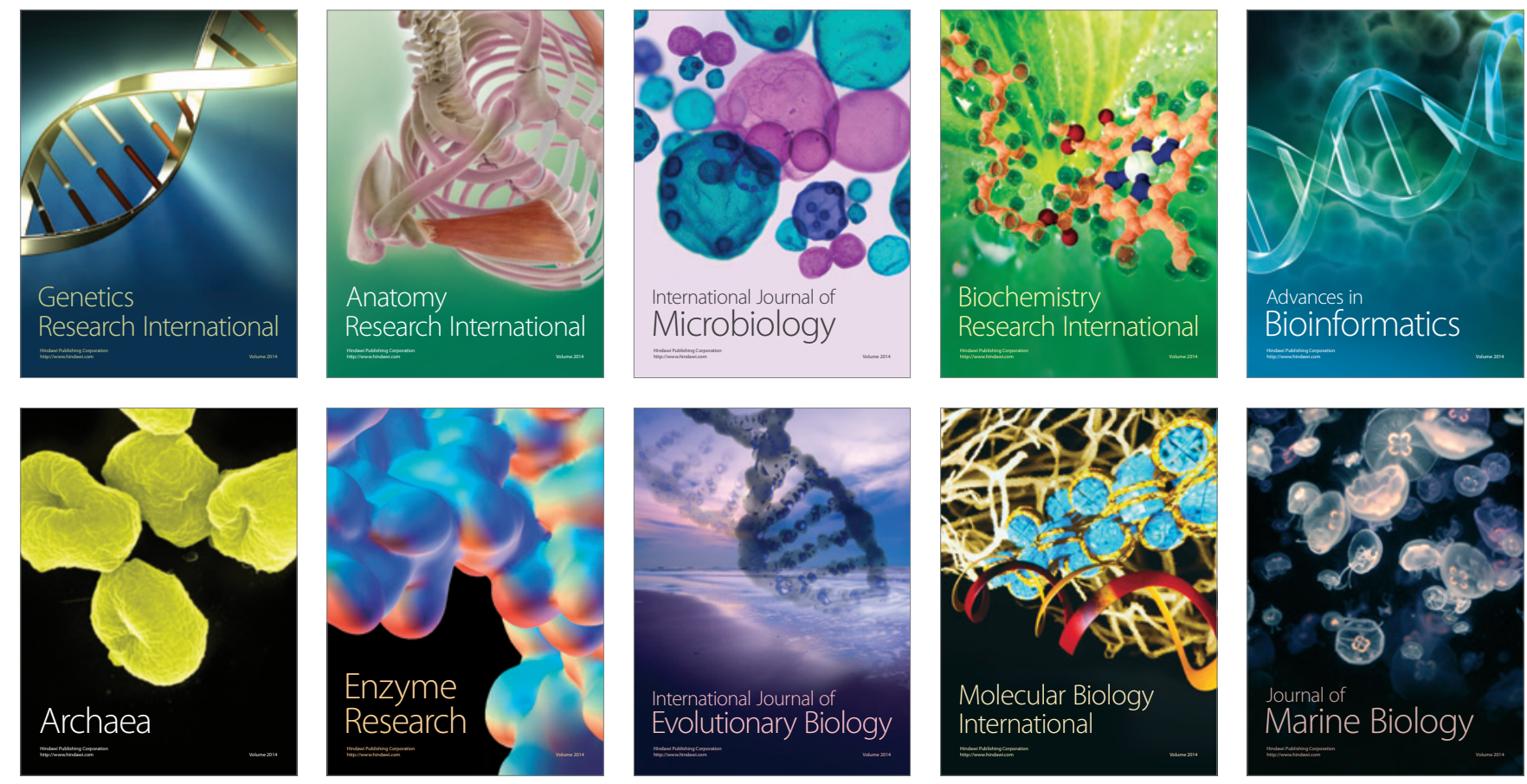